\title{
Article
}

\section{Production, Consumption, Power, and Humor in the Films of Marek Piwowski}

\author{
Mazierska, Ewa Hanna \\ Available at http://clok.uclan.ac.uk/15777/ \\ Mazierska, Ewa Hanna ORCID: 0000-0002-4385-8264 (2016) Production, \\ Consumption, Power, and Humor in the Films of Marek Piwowski. Journal of \\ Film and Video, 68 (2). pp. 14-28. ISSN 0742-4671
}

It is advisable to refer to the publisher's version if you intend to cite from the work. /10.5406/jfilmvideo.68.2.0014

For more information about UCLan's research in this area go to

http://www.uclan.ac.uk/researchgroups/ and search for <name of research Group>.

For information about Research generally at UCLan please go to http://www.uclan.ac.uk/research/

All outputs in CLoK are protected by Intellectual Property Rights law, including Copyright law. Copyright, IPR and Moral Rights for the works on this site are retained by the individual authors and/or other copyright owners. Terms and conditions for use of this material are defined in the policies page.

\section{CLoK}

Central Lancashire online Knowledge www.clok.uclan.ac.uk

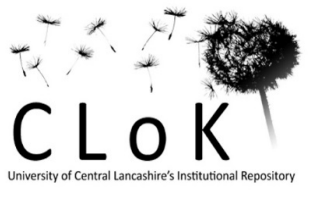




\section{Production, Consumption, Power and Humor in the Films of Marek Piwowski}

It is difficult to locate Marek Piwowski in any distinctive school of Polish cinema. His artistic output is quantitatively modest; he only made three full-length fiction films and over ten documentaries, mainly in the late 1960s and early 1970s. Being born in 1935 he was too young to belong to the Polish School, created by filmmakers born in the 1920s, and too old to be part of the Cinema of Moral Concern, which was created mostly by those born in the 1940s and 1950s. Moreover, unlike the works of Andrzej Wajda, Krzysztof Kieślowski or Krzysztof Zanussi, his films come across as unserious. However, despite the sense of not belonging to any cinematic movement, he is amongst the best loved filmmakers by domestic audiences. His Rejs [Cruise aka A Trip down the River] (1970) is described in various surveys as the ultimate Polish cult film and has its own fan club. Piwowski's other productions, such as Uwertura [The Overture] (1965) and Przepraszam, czy tu bija? [Excuse Me, Is It Here They Beat Up People?] (1976), also have a significant following, adding to Piwowski's status as the ultimate Polish cult director. This status is confirmed by frequent re-releases of his films by Polish state and private television and on DVD. It is also worth mentioning that photos from Cruise adorn covers of books devoted to wider phenomena than his films, such as a book on Polish comedy (Talarczyk-Gubała) and an edited volume devoted to the leading Polish film auteurs (Stachówna and Zmudzinski).

There are many reasons why Piwowski's films gained such a position, but the most important is his talent for capturing on camera ordinary life in Poland and heightening its most absurd features. His films combine a minute, subtle observation, pertaining to realistic filmmaking, with an affinity to create (often unintentionally, as the director claims) a metaphor; a feature conveyed by the short, general and sometimes ambiguous titles of his films, such as The 
Overture, Hair, Success or Cruise. ${ }^{1}$ However, despite the important place of Piwowski in the history of Polish cinema, there is little academic research devoted to his work, perhaps reflecting a perception that his films, being unserious, do not merit serious investigation ${ }^{2}$ and the bulk of this work is devoted to his Cruise. Moreover, while authors admit that there is a continuity between Piwowski short documentary films and his Cruise, which is a hybrid between documentary and fiction film, as well as his subsequent fiction films, they rarely investigate them in detail, typically limiting themselves to mentioning that the director remained faithful to his unique, quasi-documentary style.

In this article I will discuss the way Piwowski represents work understood as production and consumption of various non-durable and even immaterial goods, such as popular music, leisure and alcohol. My argument is that the director shuns what is regarded as the typical Eastern European setting of films about work, namely a factory and, instead, privileges places of immaterial production ${ }^{3}$. In this way he drew attention to the fact that "work" has a much wider meaning than socialist economists assumed, traditionally being preoccupied with heavy industry, hence production divorced from consumption. Instead, Piwowski is interested in such issues as production of leisure and pleasure, which appeared in Polish political and social debates only in the 1960s and gained in speed in the 1970s. He thus chronicles the attempts to modernize Poland. To account for the specificity of Piwowski's style, I will focus on his use of montage as a means to produce laughter. First, however, I shall briefly sketch the period when he made his most successful films.

\section{Poland in the 1960s and the $1970 \mathrm{~s}^{4}$}

Piwowski started his career in the late 1960s and he made the majority of his films, including his 
most successful productions, in the 1970s. By the 1960s the Second World War still loomed large in the Polish cinema and culture at large, as demonstrated by films such as Andrzej Wajda's Samson (1961) or Wojciech Has's Jak być kochana (How To Be Loved, 1962). ${ }^{5}$ Nevertheless, the rebuilding of Poland after the war's destruction was completed. Poles expected a significant improvement in their standard of living, but their consumerist ambitions were thwarted by the policies of Władysław Gomułka, the First Secretary of the Polish United Workers' Party (later Party). Gomułka was first seen as a reformist; he was a victim of Stalinism and initiated a political, cultural and economic liberalization in 1956 (so called 'October thaw' or Gomułka's thaw). However, throughout the 1960s he gradually lost the respect and trust of his compatriots and started to be seen as a conservative and authoritarian figure, who wanted his countrymen to toe the (Party) line and emulate his ascetic lifestyle. The continuous privileging of extraction of raw materials and production of machines at the expense of consumer goods and developing services meant that the promised rise in the standard of living was slow to materialise (and was even reversed in the late 1960s). In the middle of the decade the censorship was strengthened and the authorities' launched an attack on revisionist communist intellectuals, leading to the emigration of figures such as playwright Sławomir Mrożek and philosopher Leszek Kołakowski. The road down culminated in the crisis of 1968, when the Israeli victory in the June War of 1967 was used as a pretext for anti-Semitic purges and for the Party to close its ranks. It was also a time of student strikes, suppressed by security forces. Nevertheless, in the course of the 1960s Poland did achieve some cultural liberalization and economic improvement, as reflected in the flourishing of popular culture. During Gomułka’s rule Roman Polanski made his first film about rich Poles not working, but relaxing on a private boat, Nóż w wodzie (Knife in the Water, 1962) and the young people were entertained by various pop and rock musicians, such 
as the popular bands Niebiesko-Czarni and Czerwone Gitary, and Czesław Niemen, to whom I will devote more attention in due course.

Following the violent clashes with shipyard workers on the Baltic Coast in December 1970, in which several dozen workers were fatally shot, Gomułka was forced into retirement and his place was taken by Edward Gierek, who was the leader of the Party throughout the 1970s. The 1970s are often described as "Gierek's decade", partly on account on the fact that the new leader introduced a new, more personal style of government. He was often at the centre of state propaganda, with newsreels presenting him visiting factories and talking to people (Cieśliński 2006: 115-36). Another name of this period is the "decade of the propaganda of success", to reflect the upbeat tone of Gierek's rhetoric, as reflected in a slogan "to make Poland stronger and people more prosperous" (aby Polska rosła w siłe, a ludzie żyli dostatniej). Gierek, who lived and worked in Belgium for many years, before returning to Poland in 1948, recognized Poles' unwillingness to sacrifice and significantly changed his direction in comparison to his predecessors, by directing the economy toward producing consumer goods and services, introducing some market reforms and allowing citizens to be more entrepreneurial, to make up for the deficits in the state economy. He also relaxed some restrictions on traveling abroad. In his efforts in the first years of the 1970s he was assisted by an advantageous international situation, namely cheap credit, which flowed from multi-billionaire OPEC states, distributed by the international banking system in the form of loans to anyone who wanted to borrow. For the socialist countries which succumbed to this help, notably Poland, "loans seemed a providential way of simultaneously paying for investment and raising their people's standard of living" (Hobsbawm 474). During this period one could see more color on the Polish streets: a reflection of the Polish new prosperity and a desire to emulate the West, which, unlike his predecessors, the 
new leader did not thwart. However, Gierek's career, not unlike the earlier career of Gomułka, finished in the same unfortunate circumstances. Following workers' protests, resulting from the drastic worsening of their economic situation in the second half of the 1970s, Gierek lost power in 1980, which also paved the way for the fall of communism in Poland.

It should be mentioned that even in the best years of Gierek's rule the Polish economy was an economy of shortages, which affected the relationship of power between the people who possessed specific goods and those who wanted to purchase them. Although shops were plastered with posters announcing "Our customer is our master" (Nasz klient, nasz pan), the customer was not treated like the master but rather like an intruder, pestering the seller or provider of the service, often busy with more important tasks, such as earning extra money on the side. In due course I will try to demonstrate that Piwowski's films testify and comment on this imbalance of power.

\section{Military Industry}

Piwowski's first film is a 6 minutes-long documentary, The Overture, made in 1965, when he was a second year student at the Film School in Łódź. Shooting short films was part of the training of prospective film directors. Subsequently, some of these films, like those made by Roman Polanski, became famous. This was in part thanks to the high status enjoyed in Poland by documentary and short films. Poland under state socialism had a large film studio, devoted to production of documentary films. They were subsequently presented in special programs at cinemas and on television. Poland also had as a special festival, devoted to documentary, animation and short fiction films, Krakow Film Festival, one of the first and largest of this kind 
in the world, as well as a number of smaller festivals concerned with documentary films concerned with specific social issues.

The Overture is about the initiation of draftees into the army, the titular "overture", which is presented not from the perspective of the draftees, but those who are "processing" them. ${ }^{6}$ First the prospective soldiers are examined by the medical commission and later they are interviewed by the officers. This simple film structure, which includes no commentary from the filmmaker or any extraneous material, allows Piwowski to criticize certain working practices both in the army and in Poland at large. We see doctors and nurses yawning and commenting that the draftees "breed" and "multiply", which refers to the fact that instead of five, they have six men to examine till the end of their shift. Their point is reinforced by Piwowski's filming style, as he repeats many times the same basic situation and line of dialogue, although on each occasion he introduces a small change. The nurse asks each draftee the same question whether he had specific diseases, such as TB, epilepsy or broken limbs in a fast and monotonous voice, which reveals to her patients that she is not really interested in their health and even less in them as unique persons. Like a worker manning a conveyor belt, she just wants to fulfil her quota as speedily as possible, paying no attention to what passes along this "conveyer belt". Some more personal conversations are also included in the medical examination, but they are entirely on the terms of the medics. On one occasion the female doctor or nurse comments that the draftee is overweight and on another that he is too skinny. As part of the investigation the men are asked to go behind a screen and show their genitals to the nurse or a doctor, which again provokes joking comments from her. This behavior, testifying to the disregard for the young men's dignity on the part of the doctors and nurses is not premeditated, but for those, who indulge in it, appears natural, even automatic. ${ }^{7}$ This is, however, characteristic of power relations, sanctioned by long- 
lasting legal frameworks and tradition - they seem common sense. Piwowski's point is to draw our attention to the way power operates in this particular situation and by the same token denaturalize it.

In the second part of the film the officer presiding over the commission says to each man that to adhere to the principles of democracy he will ask him where he would like to go, but the draftee should respond by saying "I would like to join the air force". When one of them refuses to say it, confessing that he is frightened of heights and would prefer to go elsewhere, the officer does not hide his displeasure from hearing such a response and admits that the lack of collaboration on the part of the young man forces him to send him to the air force. Again, as in the episodes with the medics, we see a situation when the power is on one side - that of the officers. On this occasion they not only ask a question but also formulate a response. One wonders whether such a dialogue is needed at all, if its outcome is already established: the draftees have to go to the army and to join a particular unit. However, the scene shows that indeed it is needed, because the officers, representing the state power, have to pretend that they "adhere to the principles of democracy". This episode more blatantly points to the gap between the ideals of democracy, namely equality and freedom, on which the "people's republics", such as Poland, were meant to be based, and the reality, which was deeply undemocratic, where power was on the one side - the state and its functionaries. Piwowski also shows that language which was meant to obscure reality and was thus an instrument of symbolic power, to use the famous term, introduced by Pierre Bourdieu, is clumsy. This is indicated by the incorrect phrase used by the officer when he pronounces that "in order to obey the principles of democracy" (aby zachować zasadom demokracji), he will ask a draftee a specific question. This incorrect phrase can be seen as a sign of the resistance of reality to the power of lies. We can deduce further that 
socialist rhetoric was not only full of lies, but that these lies were poorly constructed, perhaps reflecting the low standards of education and cultural capital of the professional communist ideologues.

The title of Piwowski's film is very general, which invites us to regard The Overture as pertaining to something more than a particular incident of initiating the draftees into army life. The titular "overture' might be seen as an introduction to the socialist state, where people could not choose where to work or whether to work at all, contrary to what Marx envisaged in The German Ideology, ${ }^{8}$ but had to do the job allocated to them, and where they were forced to endure lies. In the last respect we can see a similarity between Piwowski’s assessment of living in Poland and that offered by Václav Havel, who in his famous essay, "The power of the powerless", referred to the case of the Czech greengrocer who for the $1^{\text {st }}$ May hangs a banner with (in this context) a meaningless slogan, taken from The Communist Manifesto, "The Workers of All Countries Unite". However, Havel's point was to criticize the conformity of the proverbial greengrocer, who accepts the lie coming from the top and perpetuates it (Havel). Piwowski, by contrast, shows indirectly that it is worth living a lie because exposing it and breaking the unwritten contract with the political authorities does not lead to overthrowing or weakening the system, only the authorities turning the screw on those who try it.

It is worth mentioning in this context that Piwowski's own life story, as told to several journalists and myself, provides a commentary about this basic situation. In the 1950s he tried to escape to the West, which enchanted him, as many young people of his generation, and was captured and sentenced for a long prison sentence. To shorten it and regain his freedom, he agreed to collaborate with the Polish secret services; the fact which was unearthed only some years after the fall of communism (Gontarczyk; Ozminkowski). In his own words, during his years of "service" he did not betray anybody, but only played a "game" with the authorities. One can say, he lived a lie, not unlike the proverbial greengrocer, but at the same through his films exposed the lie at the core of the socialist ideology and its effect on ordinary people. Nevertheless, the "outing" of Piwowski largely destroyed his legend as a chief dissident in People's Poland.

As I already mentioned, The Overture, despite being such a modest film, is recognized as one of the best films in Piwowski's career and one of the best students' films ever made in the 
Łódź Film School. An important reason for this status is its humor based on incongruity. As Jakob Ladegaard observes, this notion of congruity plays a prominent role in the modern history of humor theories, being at the centre of the definitions of wit that were developed in $18^{\mathrm{h}}$ century Britain and continue to inform such prominent $20^{\text {th }}$ century theorists of humor as Henri Bergson, Arthur Koestler and Walter Benjamin. Broadly speaking, this tradition sees wit as a primarily verbal form of humor (the joke is its clearest expression) that relies on the ability to construct and perceive similarities between otherwise incongruent ideas and entities. Wit deals in double meanings, in sudden shifts between narrative patterns and playful short circuits of cognitive categories. Comic incongruity is not necessarily political, but it can be, when the reflection it provokes is directed towards social issues. This, according to Walter Benjamin, is the case in Berthold Brecht's epic theater. For Benjamin, the essential thing about Brecht's theater is its intention to cause critical reflection on the social meaning of the stage characters rather than emotional identification. Brecht pursues this aim through constant interruptions of the narrative and any illusions of verisimilitude in ways that remind Benjamin of the montage of cinema, but which might also bring to mind the structure of a joke: the sudden disruption of the expected course of a story by an incongruent element which forces the listener to reflect (Ladegaard).

Piwowski's film might seem to have little in common with Brecht's epic theater, but montage plays an important function in it, interrupting the course of the story and bringing to the surface the gap between the ideal and the reality. In The Overture it is a gap between the expectation of people being treated with dignity, as inscribed in the country's constitution and the promise to follow Marxist rules concerning life under communism, and the everyday reality of state socialism, where people were treated like a depersonalized mass and humiliated, which the repetition of the same situation illuminates. 


\section{The Culture Industry}

Two of Piwowski's later shorts, Sukces [Success] (1968), lasting 13 minutes and 17-minutes Hair (1971), both documentaries, concern what can be described as a socialist version of the "culture industry". I'm borrowing this term from Theodor Adorno, who used it to analyze and pour scorn on popular culture, most importantly that produced in the United States (Adorno). For Adorno, the "culture industry" is an oxymoron, because culture and especially art should be created according to different rules than industry; it should be original and serve different purposes than generating income and lead to political and spiritual emancipation. By contrast, American popular culture, such as cinema and music, follow the same formula. Genre films, not unlike cars, are made as if on a kind of conveyor belt - the differences between them are insignificant in comparison with the similarities; their innovations are pseudo-innovations. Moreover, they are integrated into the capitalist economy, which for Adorno is akin to fascism (Adorno 85-92). Adorno implicitly contrasts the capitalist culture industry with that produced under the conditions of communism (Marxist communism, rather than state socialism, as practiced in the Soviet Union and Eastern Europe), where the artists, free from commercial pressures, would be able to express themselves and experiment, so that art will develop according to its own logic.

Paradoxically, nowhere were the products of capitalist and especially the American culture industry revered as in the socialist East. This being a result of the perception that the standards of work under state socialism were low and there was a mismatch between production and consumption, resulting from the lack of market mechanisms regulating production, leading to what can be described as excessive Fordization of production..$^{9}$ Moreover, the very features of 
the culture industry which put Adorno off were most admired and envied in the East. The existence of the star system and the high profitability of the American film and popular music were seen as proof that this cinema and music is of high value, because it is professional, as opposed to being the product of an undernourished, semi-amateur Eastern "cottage industry". This inferiority complex was expressed by, among other things, describing the Eastern stars by reference to their Western counterparts. For example, the iconic Polish actor popular in the 1950s and the 1960s, Zbigniew Cybulski, was described as the Polish James Dean.

Czesław Niemen (1939-2004), who is the protagonist of Success, was the most successful Polish pop singer of the 1960s. At the time Piwowski made his film, Niemen occupied the position of a trend-setter and almost a national prophet, a follower of poets such as Cyprian Kamil Norwid ${ }^{10}$, whose poetry he included on one of his records. Niemen, which was his stage name (his real name was Czesław Wydrzycki), which referred to a river which passes through Lithuania, seen as a cradle of the Polish Romantic culture and the "Eastern" way of pronouncing "w" (Polish "l”) could be seen as signs of his close links to the most noble, romantic strand of Polish culture. In his desire to be seen as an "authentic" artist, he could be compared to Bob Dylan. In the eyes of the political establishment post-thaw Niemen was a dangerous individual, due to his alleged nonconformity, Western outlook (despite Polish romantic influences) and setting the precedence of becoming very successful not thanks to acting in a group, but as an individual, nonchalantly rejecting the rigid socialist style.

When embarking on his project on Niemen, Piwowski had two basic options: to construct his portrait in a way which would please the political establishment or one that would please Niemen's fans. However, according to his own words, he did not have any specific ideological agenda. Instead, he wanted to show how the artist works. The title of the film has a double 
meaning: it refers to the title of Niemen's song and to the meaning of success according to the singer. The result, not unlike in The Overture, is humorous due to the incongruity between different parts of Niemen's answer, as well as between his statements and those of his collaborators and the clash between the sound and image. Niemen keeps saying that success (understood as fame) does not matter to him. He also dismisses his fans who ask him about tips about breaking into show business. In a romantic fashion, his song "Success" pronounces that love ('you') is the ultimate success.

Yet, at the same time, Niemen boasts about various privileges he enjoys thanks to being a celebrity, such as being allowed into a high class restaurant when it officially does not admit any guests, while also claiming that he does not take advantage of these privileges because material goods do not matter to him. In the same vein, he pronounces that everybody is an individual and he is himself absolutely unique, thanks to having a deeper contact with the essence of life. Subsequently, however, he mocks Poles wearing ties on elastic bands (epitomising here the people who follow the prudish, unfashionable and humourless Gomułka) and says that everybody should dress like him, that he should be the ultimate trend-setter. His pretensions to uniqueness and dismissive attitude to the trappings of fame are also undermined by a member of his band, who says that when Niemen presents himself as an angel, he sees a devil. The overall attitude of this colleague toward Niemen is ironic - it feels like he is well aware that behind the veneer of the blasé and spiritual artist, there is a typical pop star craving popularity.

Niemen's pretensions to originality and spirituality are also undermined by the fragments of music Piwowski chooses for his film, such as from the titular song, whose lyrics are banal and another, sung in English, which sounds like an imitation of English or American pop songs of the period. Piwowski shooting the rehearsal, which leads to repeating the same fragments of music, 
strips the performance of some of the magic, expected at a concert and draws attention to the fact that Niemen's success is the result of collaborative work, rather than the creation of one person's genius.

The film also testifies to the influence of the Western culture industry on its Polish variant. Not only does Niemen sing in English at some point, but the trumpeter excuses his allegedly playing out of tune by saying that even Armstrong did so occasionally. Furthermore, Niemen's clothes come across as an imitation of flower-power attire. By and large, although Success does not validate Gomułka’s hostility to popular culture as a force corrupting the socialist youth, it neither justifies idolization of Niemen as a new Norwid, able to lead the nation in the fight with a foreign (communist) regime. Rather, the film demonstrates a certain parallel between the official ideology and official fashion, as epitomized by men in white shirts and fake ties, ridiculed by Niemen, and Niemen's own stance, encapsulating the counter-culture as suffering from the same malaise: second-handedness, arrogance and intolerance.

Although, as with The Overture, there is no off-screen commentary, hence everything shown in the film is a "document", "is real", as the director says, such a commentary is conveyed by the juxtapositions of the images. In addition, Piwowski uses close-ups, which plays up some defects of Niemen's face, his somewhat coarse features and at times exposes his difficulty in expressing himself.

Hair, commissioned by Polish television, was a report from the $9^{\text {th }}$ All Socialist Hairdressing Art Competition for the Friendship Cup, held in Warsaw in 1971. No doubt the idea of those who funded Piwowski's endeavor was to present the socialist hairdressing industry in all its glory. Piwowski, however, circumvented this expectation, although, as in the other films, 
without adding any verbal commentary, allowing the images and words of others to speak for themselves.

When I asked Piwowski why he embarked on this film, he admitted that it was because he found something strange and funny in an "All Socialist Hairdressing Art Competition". The reason to smile was the idea that socialist authorities, known for privileging serious issues, most importantly fighting for the victory of the worldwide socialist revolution, invested in such frivolous pursuits as creating beautiful or daring hairstyles. Consequently, there was an expectation that something might not turn out quite right.

The event and the film testify to a different Zeitgeist than that which informed Success. Success represented, even if with a touch of irony, a counter-cultural artist, in conflict with official ideology, confining everybody to literally and metaphorically wearing the same tie. Hair alludes to the 1970s, Gierek's decade, when the authorities not only got softer on people like Niemen but even sponsored initiatives which were meant to add "color" to people's lives and allow the Polish culture industry to compete with its Western counterpart. The difference in approach is reflected in the choice of characters and the scale of the events. Success showed an individual artist and a small band creating their own music, even if influenced by foreign models. Hair has a group protagonist: hairdressers, their models, judges, reporters, singers and even politicians and foreign guests, all mobilized to add importance to the initiative which came from above.

The English title of the film is imbued with multiple references. First, it suggests that the main frame of reference for the competition is, as in Success, Western show business. Socialist hairdressing can only be a shadow of its Western counterpart. Hair is also the title of a famous rock musical, which was one of the most famous products of the hippie wave in the 1960s and of 
Miloš Forman's film from 1979. "Hair" in this case epitomised cultural and political nonconformity. By contrast, the event filmed by Piwowski is anything but an expression of rebellion. By giving such a title, which points to the incongruence between our expectations and what we get, Piwowski creates a humorous effect, amplified by presenting the title at the beginning in a frame which looks like the frame of a rococo-style mirror. The effect of this clash is strengthened by the use of editing and camerawork, which is investigative and suggestive.

During the course of the film the camera alternates between several planes of action and groups of people involved in the show. One of them are professional entertainers - the host presenting the show and the performers filling the time when nothing of interest happens. What is clear from their work is that they fall short of Western standards of professionalism. The host does not have much to say, so he multiplies words to fill the time. During his ramble he confesses that he does not know any foreign language, although the event is international and requires translating and negotiating national interests. The film makes much of the fact that, although Russian was at the time the hegemonic language in the Eastern bloc, no Pole shown in the film, except from professional translators, is able to speak this language. By contrast, one of the singers sings in Italian, with great emphasis trying to imitate the emotional style of Italian performers, which produces the effect of (intended, in this case) kitsch. The other performers, a duet Rinn-Czyżewski, epitomizing Polish light entertainment of this period, sing with a forced cheerfulness and neither of the performers looks glamorous. Rinn especially is overweight and dressed unattractively, which the camera emphasizes, showing in close-up the middle part of her body, with her over-ripe breasts and belly, moving rhythmically in a way which probably was meant to be seductive, but in Piwowski's camera verges on obnoxious. The shots showing Rinn's belly and hips are juxtaposed with images of shapely legs, thighs and sometimes fragments of a 
bottom of a female hairdresser, and a female member of the audience with an unbuttoned dress so that it barely covers her "private parts". It feels as if the ultimate dream of a cameraman is to catch glimpses of female genitals. There are also shots of legs touching the legs of a neighbor of the opposite sex.

Many people in the audience, mostly men, have binoculars. There is thus a parallel between what the spectators and what the camera in Piwowski's film is doing: all engaging in scrutinizing the performers and each other. This peep show can be interpreted as a commentary on the socialist world as a gigantic panopticon. That said, Piwowski suggests that in the 1970s there was a shift in this "scoptic regime": political spying gave way to erotic gazing. Such a shift affected the balance of power between men and women, because, as in the scheme described by Laura Mulvey (1975), in this regime women are the objects, men are the bearers of the gaze. However, Piwowski shows that women are not passively giving into the men's lustful gaze, but, on the contrary, they are complicit with this gaze. An example is a woman in a short dress, whose face is not revealed, who sits seductively and strokes her knees and her thighs with her manicured hand, as if inviting men to touch her soft legs. Piwowski in Hair is both the chronicler of this change and its agent, by ogling women with audacity rare in Polish cinema of this time. Despite the eroticism of the spectacle the audience is mostly yawning, maybe because the tournament started at 10 a.m. or because, despite the efforts of the organisers and performers, it is boring, testifying to the inferiority of the socialist culture industry compared to its Western counterpart.

Another group of people singled out by Piwowski are the judges and the special guests. The jury is not made up of people who know about hairdressing, but those who represent a crosssection of the population, such as a court judge, a policewoman and a nurse, all women, 
indicating perhaps that hairdressing is a frivolous occupation (although the majority of the hairdressers shown in the film are male). Such an impression is confirmed by the host who comments on the looks of the judges, rather than their ability to assess the quality of hairstyles. During the course of the film we also hear the speech of a guest from France, perhaps a chairman of some international hairdressing association. This inclusion, in the actual event and Piwowski's film, can be seen as symbolic of the good relations Poland enjoyed with the West in this period and even of Gierek's own close connections with France and French language.

The culmination of the show is a presentation of the best results in the competition. The styles of hair and clothes changed so much since Piwowski made Hair, that it is difficult to judge them in an unbiased way. However, what is clear from the images of the female models parading in front of the camera is the spirit of extravagance, permeating the show. The last model especially looks outrageous, bringing to mind the costumes sported by actors in Andrzej Żuławski’s unfinished science fiction epic, Na srebrnym globie [On the Silver Globe] (1976-87). If anything, Hair demonstrates that under Gierek the creators of the culture industry (as I believe some hairdressers can be put in this category) were able to get carried away, be extravagant and even be rewarded for that.

\section{The Alcohol Industry}

Several of Piwowski's films, entirely or in part, concern another type of 'pleasure production': that of alcohol. I will discuss here the first of these films, a 10-minutes documentary Korkociag [Corkscrew] (1971). This film takes issue with the paradox of this branch of the economy, consisting of the recognition that alcohol is bad for the human mind and body, yet allowing its manufacture and, in some cases, even treating it as a national specialty to be proud of. Under capitalism such an attitude can be explained by the requirement to produce surplus value at all 
cost, but under socialism, which was meant to be based on different principles, not generating profit, but creating a better society, a "workers' paradise", alcohol production was morally dubious. However, in reality, in Poland and many other Eastern European countries it was a well developed and important branch of industry, because it brought high returns and was significant source of so badly needed foreign currency. In Corkscrew Piwowski explores this contradiction by editing scenes from the speech of some official, representing the Polish "distillery industry", as it is labelled here, with scenes shot in a psychiatric hospital on a ward treating people with serious illnesses caused by alcohol addiction, such as psychosis, delirium, dementia and alcoholic epilepsy. The speech is fake, but according to Piwowski, it consists of fragments of real speeches and documents produced by the representatives of the Polish alcohol industry.

The official begins his address by mentioning that Poland enjoys a long tradition of producing alcohol and listing the advancement which took place in the $19^{\text {th }}$ century, during the period of industrialisation. However, a particularly important date is 1944 - the liberation of Lublin, setting up there the first Polish communist government and establishing in the same city the State Spirit Monopoly. Without any hint of irony the official talks about the challenge faced by this monopoly of ensuring that Polish vodka reaches the whole country. His discourse looks like a speech given by the Secretary of the Party (and he bears some similarity to by the time overthrown Władysław Gomułka) addressing a huge audience and indeed it is edited with images of a large audience clapping, as was customary during the Party meetings. In this way the film's director underscores the connection between the suffering and wasted lives of the victims of alcoholism and the communist state's official stance toward alcohol production. Piwowski's idea is to make the viewer aware of the connection between the production and consumption of alcohol, a link which the state refused to acknowledge, either by pretending that the alcohol 
problem did not exist in Poland (similarly as it failed to acknowledge the existence of prostitution or drug problems) or suggesting that it is a private problem of citizens. The film finishes with an announcement that the distilling industry looks into the future with confidence because the speed of producing alcohol will grow fast thanks to further technological and managerial improvements.

In common with The Overture, there a striking difference in the representation of those who provide a specific service and those who use it. The man representing the alcohol industry, as I already mentioned, looks like power incarnated. He is placed on a podium and the camerawork monumentalizes him, shooting him at times from a low angle. He gives a speech, rather than answering questions, so communication is on his own terms. The users of alcohol, by contrast, come across as completely disempowered. Those still able to talk merely answer questions, others are restrained and cannot talk at all. Their bodies are often fragmented, with the camera focusing on their most affected areas, such as trembling hands or mouth. Moreover, through the use of the intertitles, referring to specific illnesses, caused by alcohol, such as "delirium tremens" or "alcoholic epilepsy", the filmed men are stripped of any individuality and reduced to "case studies". There are two types of people in positions of authority towards them. One are the representatives of the medical profession: doctors and nurses. Their representations brings to mind Foucault's analysis of a mental asylum as a place where people were not so much cured, as subjugated to a power regime (Foucault 1977, 1978). The other people with authority are filmmakers who film the patients, most likely without the patients' consent or knowledge. In one episode we even see Piwowski, who sits next to the doctor and for a short while looks into the camera. This scene might be incidental, but even if so, it is meaningful as it acknowledges that documentary filmmaking is a-symmetrical, with power being on the side of those who shoot 
rather than those who appear in the picture. By and large, at the same time as representing and denouncing the imbalance in power in People's Poland, Piwowski points to his own position of somebody who takes advantage of the existing structures of power.

As with the other films by this director, the title is imbued with meaning. Corkscrew is used to open a bottle; it thus marks a threshold between the product and the consumer, a threshold which Piwowski explores in his films. Interestingly, although Corkscrew concerns both the production and consumption of alcohol, in the few articles devoted to the film which I found in the Polish press, the production aspect is ignored by the critics. One interview with Piwowski, undertaken in relation to the film, is entirely devoted to how best to dissuade people from abusing alcohol. Various ideas are mentioned by the interviewer and the interviewee, but neither refers to the production side, such as producing less alcohol or promoting weaker alcohol than vodka by changing pricing policies (Smółko). This silence concerning production might be incidental, but can be also interpreted as a case of self-censorship on the part of filmmakers and journalists, worried to openly challenge the mighty State Spirit Monopoly.

\section{The Leisure Industry}

I mentioned earlier that Polanski's Knife in the Water can be seen as the first Polish fiction film entirely devoted to the representation of leisure. In Polanski’s case the leisure concerns representatives of the Polish upper class and it is entirely private - on the private yacht of a wealthy journalist, far from the envious eyes of his less affluent countrymen. Not surprisingly, the film was a personal dis-favourite of Gomułka, which was an important factor in Polanski's decision to emigrate to the West. Piwowski's Cruise, made almost a decade after Knife in the Water, can be seen as a continuation of the theme of leisure initiated by Polanski, yet reflecting a 
difference of interests between those two filmmakers and the times and circumstances the films were made. The leisure in Piwowski's film is not individual but communal and is organised according to the specific rules, using people whose designated role is to entertain others. Hence, it is not just a film about leisure, but about the leisure industry. The drive towards institutionalising leisure could also be observed in the West, especially after the Second World War (Seabrook; Adorno 162-70). However, Piwowski's intention in this film is to show the specificity of the Polish version of this phenomenon. For this reason he uses a different genre than in the films discussed so far. Cruise is not a straightforward documentary, but a hybrid of documentary and fiction film. With its running time of 65 minutes, it has an unusual length for a full-length fiction film, but is longer than a typical documentary of this period, which was much shorter. It mixes professional and amateur actors, with some amateurs practically playing themselves. It does not have a straightforward narrative but is built up from short scenes, of which some are scripted, while others are improvised. It has a main character, but his role is somewhat smaller in comparison with mainstream cinema, while the secondary characters have more narrative autonomy than one expects in an ordinary fiction film. Moreover, these secondary characters are often presented embarking on a common task, creating a group protagonist, which is emphasized by cinematography and editing. Unlike a traditional fiction film, which presents dialogues in shot-reverse shot, Piwowski includes small groups talking to each other in one frame, which gives the impression that everybody in this group is equally important. The camerawork in Cruise is stylized on amateur photographs or home movies. Many of such techniques would later be used in Polish films, for example Personel [Personnel] (1975) by Krzysztof Kieślowski and eventually become a common practice, but at the time they were out of the ordinary and Piwowski was met with significant resistance when preparing his project, 
including by Antoni Bohdziewicz who was an artistic mentor of Piwowski in the film studio Tor, which produced Cruise (Zmudziński 66).

The film begins with the sign "You work on the land, you rest on the water", advertising a cruise down the Vistula river in a pleasure boat. Yet, the sign is accompanied by the handwritten information "No tickets", subtly pointing to the reality of shortages behind the façade of plenty, pertaining to the whole communist period, but especially to Gierek's decade, which the film foreshadows. The cruise is populated by people on medium to low income, reflecting its being a relatively cheap form of relaxation which does not allow its participants to enjoy much privacy. This also explains why the group is so heterogeneous in terms of education, with some people sounding like working class men and women, while others using the language of Hegel.

The main character is a chancer, who cons his way on board the boat and is taken for or an entertainment officer (Polish kaowiec, from K\&O, culture and education); a role which he accepts without protesting. Such a character would be not out of place in Western cinema; think about, for example, Steven Spielberg's Catch Me If You Can (2002). However, Western con men, as shown in the films, tend to professionals of the highest degree in their profession of cheating. Piwowski, by contrast, shows that in Poland one can become a successful con man without having any special skills. This motif is presented in an early scene when the captain interviews the chancer in order to fill a job questionnaire. It is obvious that the passenger without a ticket does not try to present himself as suitable for any profession and the captain is not interested to get the best man for the job of cultural officer. For example, he does not mind that the candidate does not know any foreign language or does not have a university education. Its absence is even seen as an asset, as alluded to in his reminiscing on a geography student, previously employed in this role, who proved unsuitable, perhaps due to being too educated. The 
captain's approach can be seen as a metonymy of the attitude to professionalism in People's Poland. The actor playing kaowiec, Stanisław Tym, described it as based on negative selection. Poland, in his opinion, was a paradise for losers and ignoramuses (Tym 14).

What follows, broadly speaking, confirms this diagnosis, but also suggests that the lack of professionalism, "bad work", can bring distinct social advantages. It can be "beautiful" or at least fun work. One way to show this is by obliterating the division between work and leisure. In Cruise we are rarely sure who is a member of the crew and who is a passenger, who is working and who is not. ${ }^{11}$ For example, there are several silent episodes, shot in the style of slapstick comedy, showing a man carrying a long pole, who passes it to somebody else, who then passes it to another person, as in a game of musical chairs. This situation can be seen as symbolic for the Polish and socialist custom of avoiding work by passing it to others, as opposed to taking personal responsibility for the task at hand. We also see some people practicing gymnastics and it is not clear whether they do it for pleasure or whether they are professional acrobats.

The passengers are expected to follow certain rules and engage in specific activities. They have to participate in the meetings called by the entertainment officer and then put their effort into preparing an event for the captain. Everybody has to do what he supposedly does best: to write a poem, sing a song etc. The role of the entertainment officer is not to entertain others but to make sure that they entertain each other and please the professional hierarchy. As in The Overture we thus witness an imbalance of power: those who are meant to provide service, do it on their own terms and expect obedience from their customers.

Although pleasure on the boat is superseded by duties, the passengers still are able to extract pleasure from the tasks imposed on them. This has to do with the two contradictory tendencies in their behavior. On the one hand, there is the desire to conform, as conveyed by an 
almost universal agreement to do what they are asked to do, in part resulting from being given an opportunity to perform. On the other hand, we witness their inability to conform, be harnessed to any project, because every idea proposed to them is circumvented either by their incompetence or their inability to reach a consensus. Consequently, they are somewhat suspended between conformity and free play. This peculiar position is reflected in the language they use, which is a mixture of different linguistic regimes: the language of a party meeting, of television information, of a philosophical or pseudo-philosophical discourse and ordinary, vernacular speech. Iwona Kurz describes the official language whose fragments one can capture in the dialogues as "the language of public discourse which penetrates, like a cancerous growth, the vernacular and everyday linguistic practices as the universal language of collected truth" (Kurz a 97). However, this official language never conquers the other types of speech; they always coexist with each other, creating an effect of incongruity. This is an important reason that the language of Cruise is so funny, as is the whole life on the pleasure boat.

Although practically all the people shown on the boat come across as incompetent, this does not prevent them from chastizing others for their incompetence. The most quoted example is a monologue of engineer Mamoń, played by iconic actor, Zdzisław Maklakiewicz, about the low quality of Polish cinema. Mamoń complains that nothing dramatic happens in Polish films, therefore they are boring, and the actors played in them are not expressive. He also asks rhetorically why Polish films cannot be like foreign films, by which he means Western or even American films. This question, as I already mentioned, is explicitly posed in Piwowski's documentary films, such as Success and Hair. Mamoń's tirade remains unanswered, which can be seen as an invitation for the viewer to answer him/herself. Cruise and its afterlife can also be seen as an answer of sorts, by demonstrating that a film can be made according to the opposite 
standards than those followed by the American "culture industry", yet achieve success on its own terms, as testified by its cult following. I will argue that to some extent this refers to the performances shown in the film. They are not great according to Western standards of professionalism, yet they have their own charm.

Throughout most of its afterlife Cruise was perceived as a satire on life in socialist Poland, marked by excessive bureaucracy, acceptance of mediocrity and state interference in the private affairs of citizens. In this respect the opinion of a film historian, Małgorzata Hendrykowska, is symptomatic. She argues that Cruise provides a metaphor of Poland as a “cage", hence a totalitarian state (Hendrykowska 156). ${ }^{12}$ Somewhat different opinions emerge from a questionnaire among Polish film and media historian, conducted some years ago by Polish journalist, Bronisław Tumiłowicz, in connection with a possible sequel of Cruise, planned by Piwowski. While some suggested, like Hendrykowska, that the film captures the totalitarian character of life in state socialist Poland, others argued that it offers an "eternal" portrait of Polish society or even that this portrait might awaken nostalgia (Tumiłowicz 2010). ${ }^{13}$

\section{$\underline{\text { Conclusion }}$}

I mentioned at the beginning that Piwowski, despite his modest input, has an important place in the history of the cinema of Poland's People's Republic. I argued that this place results from his chronicling the transformation of Poland from a country producing material goods to that in which culture and pleasure is also mass produced. Another important characteristics of his work is his desire to show the connection between production and consumption or providing and receiving a service. Piwowski demonstrates that in Poland the producers overpowered 
consumers; the latter were often at the mercy of the former. Despite that, the citizens were able to enjoy some freedom and extract pleasure from the situations in which they were situated. Piwowski's main method to show this imbalance of power was a highly inventive montage of documentary or quasi-documentary material, based on repetitions or putting together contrasting images, which created a humorous effect. In this way Piwowski achieved a double effect: his films appear to be true (which is the desired effect of documentaries) and have a strong critical edge.

\section{Special Note}

The research for this article was supported from the grant from Polski Osrodek Naukowy w Londynie.

The author expresses her gratitude to Iwona Kurz, Elzbieta Ostrowska and Mirosław Przylipak for their comments on the earlier drafts of this article.

\section{REFERENCES}

Adorno, Theodor The Culture Industry: Selected Essays on Mass Culture. London: Routledge, 1991 [1972 and 1976].

Cieśliński, Marek. Piękniej niż w życiu: Polska Kronika Filmowa 1944-1994. Warszawa: Trio, 2006.

Crampton, R. J. Eastern Europe in the Twentieth Century - and After, second edition. London: Routledge, 1997.

Davies, Norman God's Playground: A History of Poland, vol. II, 1975 to the Present, revised edition. Oxford: Oxford University Press, 2005 [1979].

Foucault, Michel. Discipline and Punish: The Birth of the Penal System. New York: 
Vintage, 1977.

Foucault, Michel. The History of Sexuality, Vol. 1: An Introduction, trans. R. Hurley. New York: Pantheon, 1978.

Gontarczyk, Piotr. “Rejs w kłamstwo”, Wprost 11, (2007): 28-31.

Havel, Václav. "The Power of the Powerless". The Power of the Powerless. Ed. John Keane.

London: Hutchinson, 1985: 23-96.

Hendrykowska, Małgorzata. “ Marek Piwowski wyrusza w 'Rejs'”. Historia kina polskiego. Ed.

Tadeusz Lubelski and Konrad J. Zarębski. Warszawa: Fundacja Kino, 2007: 155-57.

Hendrykowski, Marek. Rejs. Poznań: Wydawnictwo Naukowe UAM, 2005.

Hobsbawm, Eric Age of Extremes: The Short Twentieth Century 1914-1991, Abacus: London, 1995.

Kurz, Iwona (a), "Not Having to Stick to the Point: The Fly Killer by Marek Piwowski'. Polish New Wave: The History of a Phenomenon that Never Existed. Ed. Łukasz Ronduda and Barbara

Piwowarska. Warszawa: Instytut Adama Mickiewicza, CSW Zamek Ujazdowski, 2008. 96-9.

Kurz, Iwona (b). “'Our Folks': Ordinary People in Czechoslovak and Polish Cinema around 1968'. Visegrad Cinema: Points of Contact from the New Waves to the Present. Ed. Petra

Hanakova and Kevin B. Johnson. Praha: Katedra Filmovych Studii FF UK, 2010: 99-109.

Ladegaard, Jakob. "Laughing Matters: Four Marxist Takes on Film Comedy". Marx at the Movies: Revisiting History, Theory and Practice. Ed. Ewa Mazierska and Lars Kristensen. Houndmills: Palgrave Macmillan, 2014. 102-22.

Lazzarato, Maurizio. “Immaterial Labour". Radical Thought in Italy: A Potential Politics. Ed. Paolo Virno and Michael Hardt. Minneapolis: University of Minnesota Press, 2006. 132-46. Lukowski, Jerzy and Zawadzki Hubert. A Concise History of Poland. Cambridge: 
Cambridge University Press, 2001.

Marx, Karl and Frederick Engels. The German Ideology, Parts I and III. New York:

International Publishers, 1947.

Mazierska, Ewa. "International Co-productions as Productions of Heterotopias". A Companion

to East European Cinemas. Ed. Aniko Imre. Oxford: Wiley-Blackwell, 2012. 483-503.

Mulvey, Laura. "Visual Pleasure and Narrative Cinema". Film Theory and Criticism. Ed. Gerald

Mast et al. Oxford: Oxford University Press, 1975. 746-57.

Ozminkowski, Violetta. "Ja i mój ubek", Newsweek Polska 10 (2007): 80-5.

Seabrook, Jeremy. The Leisure Society. Oxford: Blackwell: 1988.

Smółko, Ewa. “Pijesz - robisz sobie krzywdę” WTK 21 (1974): 16.

Stachówna, Grażyna and Bogusław Zmudziński. Ed. Autorzy kina polskiego, Volume 3.

Kraków: Wydawnictwo Uniwersytetu Jagiellońskiego, 2007.

Talarczyk-Gubała, Monika. PRL się śmieje: Polska komedia filmowa lat 1945-1989. Warszawa:

Trio, 2007.

Tumiłowicz, Bronisław. “Piwowski wyrusza w kolejny Rejs”, Przeglad 42, (2010).

http://www.przeglad-tygodnik.pl/pl/node/15669, accessed 16/09/2013.

Tym, Stanisław. "Jeszcze raz o Rejsie”, Gazeta Wyborcza 171 (2000): 14.

Zmudziński, Bogusław. “ Marek Piwowski - powaga śmiechu”. Autorzy kina polskiego, Volume

3. Ed. Grażyna Stachówna and Bogusław Zmudziński. Kraków: Wydawnictwo

Uniwersytetu Jagiellońskiego, 2007. 53-85.

\section{NOTES}

${ }^{1}$ In this respect Piwowski's cinema resembles that of his better known compatriot, Krzysztof Kieślowski, who also gave his documentary films general titles, such as The Office or The Factory.

${ }^{2}$ The exceptions are two essays, written by Iwona Kurz (a and b). Several studies on Piwowski, although published by academic press, barely exceed journalistic works (for example Hendrykowski, Zmudziński). ${ }^{3}$ I use the term "immaterial production" after Lazzarato. In his conceptualization, immaterial production is one which produces immaterial goods, such as affects or ideas.

${ }^{4}$ Due to space constraints, I'm only identifying here the main features of this period. A more thorough discussion can be found in Davies 437- 81; Lukowski and Zawadzki 260-71 and Crampton 359-66. 
${ }^{5}$ The Second World War is also present in some of Piwowski's films, including Cruise, but this aspect of his films has little relevance to my discussion.

${ }^{6}$ Military service was compulsory in Poland, in common with other Eastern European countries. Men without university education were expected to join the army for two years; graduates for one year.

${ }^{7}$ Such understanding of power as difficult to pinpoint, flexible, amorphous, unspoken, yet omnipresent and pervading, to which Piwowski refers in this and his other films, is close to the concept of power introduced by Michel Foucault. For example, Foucault is right to assert that "[p]ower is everywhere; not because it embraces, but because it comes from everywhere" (Foucault 93).

${ }^{8}$ The German Ideology includes this passage which captures the life under communism: "In communist society, where nobody has one exclusive sphere of activity but each can be accomplished in any branch he wishes, society regulates the general production and thus makes it possible for me to do one thing today and another tomorrow, to hunt in the morning, fish in the afternoon, rear cattle in the evening, criticize after dinner, just as I have a mind, without ever becoming hunter, fisherman, shepherd or critic" (Marx and Engels 22).

${ }^{9}$ For example, if there was a transport of shoes or underwear to the shops, it would be unlikely all sizes will be on the shelves. By the same token, a few pop artists monopolised Polish scenes and the media, which ensured longevity of their careers, but gave audiences little choice.

${ }^{10}$ Norwid is regarded as one of the greatest Polsh romantic poets. Moreover, he has an aura of tragedy about him, as he was regarded as a non-conformist and a large part of his life he spent abroad, living in poverty.

${ }_{11}$ This can also be seen as a reference to the difficulty of establishing who in Poland (and Eastern Europe at large) was employed to work and who was employed to spy on others. There are other instances in the film which can be regarded as an allusion to spying and its consequences, for example at the beginning we see a man approaching a boat but he is not among the passengers. This might be due to being captured by secret services.

${ }^{12}$ I suggest that it will be more productive to use here a metaphor of "heterotopias", which I applied to another ship, presented in Polish film, the spaceship in Test Pilota Pirxa [The Test of Pilot Pirx] (1979), directed by Marek Piestrak (Mazierska).

${ }^{13}$ Piwowski himself today sees his film not so much as a critique of the socialist Poland, but as a document about better times. He confessed to me that his life in the 1970s was too easy, too comfortable, which led him to missing many opportunities to make films. He appreciates this easiness of making films in the 1970s especially against the background of the new rules, introduced in the last decade, when the process became more market-oriented yet also more bureaucratic, with many specialists assessing the quality of the project. This, in his opinion, paradoxically does not lead to films which are either especially original or attracting many viewers, but rather producing films following the same formula. 